\title{
New public service based on citizen centric on Malang licensing services in era of decentralization
}

\author{
Dwi Suharnoko, Umi Chayatin, Chandra Dinata \\ Public Administration Departement, Faculty of Social and Political Sciences \\ University of Merdeka, Malang
}

An important point in good governance is Essentially the provision of excellent service to people who have citizenship rights that must be provided by the government. Globalization has encouraged the paradigm changes in government in carrying out its distributive function to the community. As much as developed countries have done, public encouragement accompanied by public participation in all governance processes leads the country to a "virtual" spaces with sufficient coverage to Facilitate its citizens to Participate in all national and state affairs, the autonomy of space given to the region is Able to Make local Governments self-reliant, innovative, and creative in providing services to the community. The research conducted in the Integrated Licensing Service Agency of Malang Regency shows that the satisfaction of the society is good enough to the service product given, if it is Categorized the assessment from the public perception of the service given is A (very good). To achieve that, of course, the integrated licensing agency of Malang regency through a long way to reach it starting from building a mutual commitment to change the more autonomous institution in carrying out the service function to the society.

Key word: citizen centric, licensing service reform, service innovation

\section{Background}

Regional autonomy proposed by the Government to deliver these areas to live independently and be innovative in good governance (good governance), especially in providing the best service to the people. Through the decentralization policy, the efforts of the bureaucracy in providing services to the public. provide spaces that are not too complicated services and tersentralistik. This means that through decentralization, local governments can shorten the span of control of the policy (span of control) to the people.

Malang Regency is located at an altitude of 250-500 asl, with an area of $3,535 \mathrm{~km}^{2}$. 33 Subdistricts are distributed to provide excellent service to the community, with 378 Villages and 12 Kelurahan that provide direct services to the community. The smallest element of the community that is spread by the administrative authority of the government as the spearhead of services based on local trusts such as the pil- 
lars of the community and neighborhood groups spread throughout the sub-district. Therefore, a total of 3,125 neighborhood associations (RW) and 14,352 neighborhood units (RT) became partners in the government's work to increase citizen participation in development. Based on BPS (2016) records, the total population is 2,544,315 people spread across 33 sub-districts, 378 villages, 12 sub-districts.

Malang also known as an area rich in potential such as agriculture, plantation, medicinal plants and so forth. Besides, also known tourism objects, both natural tourism, cultural tourism, historical tourism, and religious tourism.

During the ongoing regional autonomy in Malang, local government is trying to attract investors to ivestasinya, develop the economy, while encouraging the creation of a healthy business climate and the welfare of society. Therefore, promotion of the region continue to be pursued as such by the local government to attract the sympathy of those investors. In line with this, the question that arises is the system of licensing services that are not effective and efficient a factor inhibiting the presence of investors to invest in the area,

Promotion of the region to get investors in development is not accompanied by care reform makes investors dissuade caused by the maintenance business licensing convoluted, the maintenance of the 'scattered' and time consuming (there is no certainty of completion) and the cost is quite high, but it is fertile the practice of "extortion" create a sense of comfort investors lost. Therefore, nobody can dielak else will happen is the low level of investment. When the investment is lost then the impact on employment and regional income will be reduced. The question is, why does this happen?

This problem is caused by the system services that do not neatly arranged, the lack of commitment by the government bureaucrats, lack of creativity and innovation cowardice and bureaucratic work culture that is low as a primary driver in a bad service, especially the licensing service. In principle, this problem is formed because of the lack of visionary leadership.

\section{Literature review}

\section{Autonomy Policy: Initiation of Integrated Service System Policy}

A mission run by the government of Malang regency is to create entrepreneurial bureaucracy, the bureaucracy more customer oriented. That is the paradigm of bureaucracy serving the community, so as to increase the number of community satisfaction with the services provided on the affairs of the government bureaucracy service. According Ratminto and Winarsih (2010: 42) pattern paradigm change a service like this is a cultural change that is based on the organization's work force intact human resources in an organization.

As a rule alienated by the central government, regional autonomy is executed can not be separated from the general central policy of the central government. Circulation centralized policies issued by the central government as the basis for policy making tactical done by region for applying the vision and the mission area for the 
public welfare. For example, in order to realize the system of licensing services oriented to the user (user). Since the reform era, the Minister of the Interior instructed to memeberikan area of one-stop service to the community. its purpose is to provide convenience to the user community in dealing services.

\section{Citizen Centric As Pedestal Quality Improvement Services}

The main message is fundamental to the concept of citizen centric delivered by Kalam (2005) is to make government more open to the people to participate in every step of the decision-making. People as citizens with rights with obligations continue to be encouraged and facilitated by the government to monitor the governance of the State, especially for democratic nations. In principle, a citizen centric substance 'humanism' is done by some developed countries-developing in its discretion as part of a strategy of creating a good service to the community, supported by the community needs to be "technology-information", it is based on community resources are increasingly increased (Kearney, 2009).

The mainstream of the service changes, held in the context of governance in many developing countries provide important lessons related to the agenda of governance reform for developed countries. Technology becomes a mediator to get closer and at the same glue harmonious relationship between elements of the community, business, and government becomes a government order system. Therefore, the concept of citizen centric strongly encourage awareness of all parties in carrying out their respective functions.

The parties in question is the government as a regulator and mediator for joint prosperity in accordance with the principles of justice, other term studies in public administration developed by Fredrickson (2010) is a "social equity" in the construction of which was held by the government. Meanwhile, a group of private (business) is a user and may also be the government's partner in running the distributive function of the state in providing public services. While the last element is positioned as a user community that is the subject and object of government policy.

The concept of a citizen centric governance structure symmetrical relationship in hinting government transparency in managing available resources (transparency) is intended for the common welfare. For such openness, tekologi and information (IT) which will bridge the government in organizing his administration is transparent. If it is associated with a dense population and geographical location between the region (district) apart, then it is very relevant for the government to meg "ideology" basic right of citizen centric services with more touching corner to public needs.

Study of administrative reform in the field of public service performed by Kearney (2009) put justice and human rights as the basis for implementing services based on citizen centric. There are seven characteristics of citizen centric disclosed by Kearney (2009: 3-7) for governance, namely: first, changes in parenting is done by the government organization in capturing public issues. Decision-making by the government do with the basic needs of the public are delivered in a participatory 
manner by the public; second, cultivating strong leadership in the management of the organization is needed to strengthen the organization's vision. With good management of an organization, making the management as the main characteristics in governance. Visionary leadership more emphasis on public desire communal than individual desires; Third, build a culture and values in the organization is important to support the passage of public organizations with citizen centric. Tatanilai system adopted by a person (people) will be integrated in the work culture of the organization. Tatanilai which are intended to be honesty, perseverance, progressive, and unyielding in the effort to achieve the objectives of the organization, in the language Kearney (2009), also known as the working culture of the organization; Fourth, build strong relationships between customers to sustain a program provided by the government. In this context, the government is providing accurate population database system to assure and build networks between sesam beneficiaries of the policy. Its function positioned submitted by Kearney (2009) is to maintain the interaction and improve quality of services provided by the government to its people. Osborne and Gaebler (1992) mentions this condition as the placement of business governance system into governance. The business model in caring for the sustainability of product sales network in order to gain an advantage over the products it sells; Fifth, increase organizational work system. Working system is meant governance organizations that use information technology as a basis for the development of an organization's network. This is based on changes in the governance paradigm era of globalization; sixth, managing organizational performance in a professional and responsive on any changes in the era of globalization, terlebihn able to put the values espoused socialist governance into the organization so as to produce a good performance of the organization. And seventh, it is no less important in developing government institutions based on citizen centric is the sustainability of public support for decisions made by the organization (government). The impact of social and economic impact in every decision issued by an organization to improve the quality of life in society is supported by the amelioration of klemahan of previous policies. it is no less important in developing government institutions based on citizen centric is the sustainability of public support for decisions made by the organization (government). The impact of social and economic impact in every decision issued by an organization to improve the quality of life in society is supported by the amelioration of klemahanof previous policies. it is no less important in developing government institutions based on citizen centric is the sustainability of public support for decisions made by the organization (government). The impact of social and economic impact in every decision issued by an organization to improve the quality of life in society is supported by the amelioration of klemahan of previous policies.

Of the seven characteristics for the organization of citizen centric public (government) is a form of government award given to its citizens, in this case the system of democratic governance will encourage the full participation of citizens to keep and care for their own people (nasionalism). 


\section{Methodologic}

A qualitative approach was used to achieve in-depth information on issues affecting the service provider licensing with the public as users of these services. Therefore, the method used is descriptive qualitative by using the technique of "Probability Sampling - stratified sampling" in exploring information and analyzed using interactive methods of analysis models such as those developed by Miles and Haberman (Sugiyono, 2009).

\section{Research result}

\section{Strengthening Institutional Capacity}

Care system licensing policy applied by the government of Malang Regency amended on the basis of performance evaluation. The evaluation found that the need for change in the system furnish services to the community, especially in the field of licensing judging from the institutional side. In addition, the capacity of existing resources is still far from institutions in dealing with licensing requirements. In each of the services provided, although of institutional arrangement have been repaired, but still has not shown professionalism in providing services particularly in the field of licensing.

Therefore, evaluating the policies carried out to fix the system of licensing services were good with logic that is used on the evaluation is to attract investors to invest in the construction in Malang with an effective and efficient licensing.

From 2004 a licensing service unit with the one concept was formed to build commitment in providing services to the community, especially in the field of licensing services. Then in 2007, a one-stop integrated service unit underwent institutional change into a technical institution called the licensing service. This change is of course based on strategic studies starting from the demands of the community for the services provided to improve the quality of services provided by Malang Regency to the community. Jasin et al (2007) in his research stated that changes from forms to other forms of licensing service systems were carried out due to the lack of transparency requirements, certainty of time, accuracy of costs, procedures, and speed of completion of applications submitted by applicants. This legitimizes the evaluation results of the Malang Regency Government on the performance achievements of the licensing service for one year and has not been able to reach the target. The community's enthusiasm is very high for the services provided, but in terms of completing the permit application, it still uses traditional patterns. The point is, the service pattern provided is still complicated so that it takes a long time for one type of permit.

System integration services is a separate issue that occurs on the provisions of Regents policy to streamline services, especially megefektif and licensing services in Malang. Therefore, the consolidation process and the perception by the Regent as the leader in local government. 
Changes for changes in licensing services are increasingly being felt by the community. This is indicated by an increase in the index of community satisfaction with the services provided by the government to the public. Answering the challenges of the changing times, Malang Regent continues to coordinate with the legislature together to find the ideal form in the provision of licensing services in Malang Regency.

Four years running and operation of UPTP, UPTP institutional status increased to the Integrated Licensing Service Agency (BP2T) in the year 2012. This was done to integrate each work unit serving the public service in order to avoid overlapping programs.

Institutional reform efforts for services continue to be pursued by the Government of Malang Regency. Since the change of the paradigm of service in Malang, make this district as a destination for other regions to learn to apply the integrated services. Therefore, the District Government together with Parliament continues to evaluate policies that have been implemented.

\section{New Public Service As Applied: Integrated Service System Policy Implementation}

Shifting the theoretical concept of "public management" into "public service" by Denhardt and Denhardt (2007) is a chain that can not be separated from the role of public administration. Therefore, a change of public management, which focuses on the management of public goods (public goods) is good and right for the common good. Meanwhile, in the conception of public service, the management of public goods (public goods) undertaken by the government so efficient for the benefit of society, where the designation is not far from the spirit of the beginning of providing spaces (space) for the public to mendapatkannnya. Furthermore Denhardt and Denhardt explained that the shift from public to public service management is a change from the way the system state that menunut participation of each element (stakeholders) with democratization running. On this basis oriented service to the user (user) services into a commitment that is not negotiable.

A fundamental change of the system of licensing services in Malang entered a new phase in 2004 with the establishment of an Integrated Service Unit One Roof (UPTSA) to this day continues to develop innovative policies to better provide the best color for the investment areas that would be able to "boost" the local revenue ,

UPTSA formation with the main objective to overcome belitnya convoluted licensing services provided by the government to the public so as to make the government deteriorated image in the eyes of its people. Moreover, the bureaucratic culture that develops when it is a patrimonial bureaucracy so much going on "extortion" of each of the necessary permits.

Formation Unit to serve the public services in an integrated manner is a regional strategy to bring a good image to the public. Albert and Zemke (in Ratminto and Winarsih, 2010: 79-80) states that organizations that are engaged in the service will be successful when it has three similarities, namely; First, the formulation of a good service strategy; second, putting people oriented customers / consumers at the forefront; and 
third, customer friendly system. Ratminto and Winarsih (2010) states that all three of these factors must be managed properly to achieve customer satisfaction (service users). Therefore, the strategies developed by the region to form a UPT expected to answer the problems experienced by the region and the community. Public complaints against the complexity of the service makes the area not visited by the investors. The regional strategy is a form of interaction between systems, community (customer), and human resources are owned by the county. This concept was developed by Albert and Zemke (in Ratminto and Winarsih, 2010: 80) as the service triangle.

Institutional changes are inevitable to answer the question within a certain time in the era of globalization. Changing UPTSA, Office, until BP2T is change the management authority to formulate technical policy fields of integrated services, the separation between licensing and non-licensing services, as well as the existence of a special section to deal with public complaints. This change brings consequences position level adjustment and development of more specific organizational functions.

BP2T formed not leave the substance of the initial formation of the spirit of service as a service unit door. BP2T headed by a Chief who oversees the functional position and the administration as well as other sub-sections to cater to the specific needs of the community.

Changes that occur in the structure of government bureaucracy Malang regency in the context of public service is a manifestation of the government's commitment to achieve the bureaucratic entrepreneur with orientation on customer satisfaction (the service user). Professionalism established within the institutional BP2T will lead to satisfaction for the community because the services provided will be convenient, fast, and cheap. Thus the area will get the results of its work, the increasing revenue as investors feel safe and comfortable in investing in Malang.

Maturation of strategy in building an institution (institution development) makes BP2T as an established institution in the performance of its services. It is closely linked to the strength of the institution with adequate human resources. Basically, human resources are the backbone of the organization that determines the good and bad of an institution, especially providing services to the public. As explained by Ratminto and Winarsih (2010: 42) that the main factor that makes an institution that was nice in providing public services are human resources that exist therein. That is, the bureaucrat in charge of providing services to the public must be absolutely anyone who has a high capability as well as have the ability or expertise in their field.

In an effort memnjadikan BP2T strong institutions, initially built a solid foundation to prepare human resources in institutions (capacity building). Beginning with selecting human resources selected in accordance with the competence of each satker technical (work unit) in the environment as government Malang, then choose a reliable workforce with the ability and expertise needed by the body to enable the transfer of knowledge to other employees , Besides other measures taken by the institution to make a sturdy institution is to provide trainings in internal and external with the aim of building a new culture of the organization, creating values of a new work in the organization. And do not forget the efforts institutions in regeneration. 
To encourage motivation and incentives given to employees varied tailored to the capabilities and performance.

As the capital in providing the best service for the public, currently existing human resources in BP2T vary widely, the following is data on the number and level of education BP2T pewagai in Malang:

Table 1

The number and Employee Education Level BP2T

\begin{tabular}{|c|c|c|c|c|c|c|c|c|c|c|c|}
\hline \multirow[b]{2}{*}{ No } & \multirow[b]{2}{*}{ Eselon } & \multicolumn{4}{|c|}{$\begin{array}{c}\text { Golongan/ } \\
\text { Ruang }\end{array}$} & \multicolumn{6}{|c|}{ Pendidikan } \\
\hline & & IV & III & II & $\begin{array}{l}\text { I/ } \\
\text { Non } \\
\text { Gol }\end{array}$ & SD & SLTP & SLTA & D3 & s1 & S2 \\
\hline 1. & II & 1 & - & - & - & - & - & - & - & - & 1 \\
\hline 2. & III & 4 & 1 & - & - & - & - & - & - & 3 & 2 \\
\hline 3. & IV & - & 3 & - & - & - & - & - & - & 2 & 1 \\
\hline 4. & Staf & & 21 & 6 & - & - & - & 11 & 1 & 15 & - \\
\hline 5. & Honorer & - & - & - & 4 & 1 & - & 3 & - & - & - \\
\hline \multicolumn{2}{|c|}{ Jumlah } & 5 & & $\begin{array}{l}6 \\
40\end{array}$ & 4 & 1 & - & $\begin{array}{c}14 \\
40\end{array}$ & 1 & 20 & 4 \\
\hline
\end{tabular}

Source: BP2T Malang.

\section{Discussion and implications}

Although institutionally has been strong, but in carrying out its performance, the agency experienced technical problems while performing licensing services. It dikernakan lack ikhlasan most departments/institutions in hand over all the duties and functions of service to BP2T, then coupled with the distance between the area per subdistrict very much when people do the necessary permits in the Capital District of Malang. Keep in mind the amount District in Malang today includes 33 Districts geographical characteristics different from one another.

Stagnationservice functions caused by ketidakikhlasan, as the author explained, this phenomenon occurs because the "egocentricity" of the work that resulted in duplication of work done by other agencies. Therefore, with a mature strategy carried out consolidation facilitated by the Regent to the perception and objective that services provided to the public to be optimal so that it can memcu economic growth at the macro level, Malang.

After the consolidation is done, the entire department/agency in charge of providing services to the community as a parent BP2T submitted to the ministry. While agencies/other agencies serving as Trustees, targeting PAD, set levies, as well as a technical team field. BP2T as a repository of information and a center for community services. thus, the technical offices no longer directly deal with the public service because it has been handed over authority to the BP2T (this concept is known as the concept of meritocracy). 


\section{Restoration Bureaucracy: Employee Performance Evaluation}

In evaluating the performance of employees BP2T environment, institutions have a regular evaluation system to measure achievement, dedication, and loyalty. System performance is measured for each individual employee to see the performance of the work done on the principle that has been set by BP2T. This is the standard applied to raise the level of karispegawai BP2T environment.

\section{Implications Against Target Group}

Licensing services in an integrated system that is applied by Malang Regency Government currently provides a variety of conveniences for public service users as people who need a business license, permit open physician practices, building permits, and so forth. The process of obtaining licenses obtained is not convoluted serpentine, meaning that the licensing process is not passed through many tables as perceived prior to the integrated licensing policy.

In addition to the use of public services in the process of licensing the licensing easy, there are some of the most fundamental changes are given by BP2T namely by serving a wider variety of services when compared with the past. Formerly, licenses implemented by each agency is different, after the integrated service policy transferred to a special institution that is CPM. Currently the number of types of services are handled by BP2T as in the table 2 .

Licensing Services BP2T type in Malang

\begin{tabular}{|c|l|}
\hline No. & \multicolumn{1}{|c|}{ Type of Licensing Services } \\
\hline 1 & Allotment of Land Use Permit (IPPT) \\
\hline 2 & Building Permit (IMB) \\
\hline & a. Socio-cultural \\
\hline & b. Business \\
\hline & c. Housing \\
\hline & d. residential \\
\hline & e. Religious \\
\hline & f. Other functions \\
\hline & - Advertising \\
\hline & - Tower \\
\hline 3 & Wetlands Permit Changes Being Dry Land (Beririgrasi Land Transfer Function) \\
\hline 4 & Establishment Permit Building Above Public Bodies \\
\hline 5 & People's Mining Permit (IPR) \\
\hline
\end{tabular}




\begin{tabular}{|c|c|}
\hline No. & Type of Licensing Services \\
\hline 6 & Exploration Mining Business License (IUPE) \\
\hline 7 & Production Operation Mining Business License (IUPOP) \\
\hline 8 & Electricity Supply Business License To Own Or Public Interest (IUPTLSU) \\
\hline 9 & Mining Services Business License (IUJP) \\
\hline 10 & Route permit \\
\hline \multirow[t]{3}{*}{11} & Disturbance Permit (HO) \\
\hline & a. Business \\
\hline & b. Tower \\
\hline 12 & Environmental permit \\
\hline 13 & Liquid Waste Disposal Permits \\
\hline 14 & Temporary Storage permission Limabh B3 \\
\hline 15 & Liquid Waste Utilization Permit For Application to Land \\
\hline 16 & B3 Waste Management Permit \\
\hline 17 & B3 Waste Collection Permit District Scale (Except Olie) \\
\hline 18 & Licensed Aircraft Usage Steam (Ippu) \\
\hline 19 & Livestock Business License (IUP) \\
\hline 20 & Permit Expansion Ranch (IPUP) \\
\hline 21 & Fishing Permit (IUPI) \\
\hline 22 & Fish Cultivation Business License (Iubi) \\
\hline 23 & Approval in Principle (PP) \\
\hline 24 & Warehouse Registration (TDG) \\
\hline \multirow[t]{5}{*}{25} & Trading Business License (License) \\
\hline & a. Small \\
\hline & b. secondary \\
\hline & c. Big \\
\hline & d. Siukan \\
\hline \multirow[t]{3}{*}{26} & Advertising Provider License \\
\hline & a. Incidental \\
\hline & b. Permanent \\
\hline 27 & Shelter Permit Prospective TKI \\
\hline 28 & Establishment of Special Work Permit Exchange (IPBKH) \\
\hline 29 & Permit extension Hiring Foreign Workers (IMTA) \\
\hline 30 & Licensed Abattoirs (IPH) \\
\hline 31 & Licensed Veterinarian Practice (IPDH) \\
\hline 32 & Industrial Business License (IUI) \\
\hline
\end{tabular}




\begin{tabular}{|c|c|}
\hline No. & Type of Licensing Services \\
\hline 33 & Licensed Private Training Institutions (ILKS) \\
\hline 34 & Ground Water Usage Permit (IPAT) \\
\hline 35 & Groundwater Exploitation Permit (IUAT) \\
\hline 36 & Establishment Permit Fuel Filling Station To General (Gas Station) \\
\hline 37 & Interpreter Drill Permit (West Irian Jaya) \\
\hline 38 & Groundwater Permit Drilling Company (IPPAT) \\
\hline 39 & Plastering permission Springs \\
\hline 40 & Water Usage Permit and Springs \\
\hline 41 & Permission pantek wells \\
\hline 42 & Monitor wells Manufacture Permits \\
\hline 43 & Well Water Utilization Permit Pengambilandan PANTEK \\
\hline 44 & Ground Water Drilling Permits \\
\hline 45 & Establishment Permit Courses and Training Institute (CGC) \\
\hline 46 & Establishment permit Community Learning Center (CLC) \\
\hline 47 & Licensed Child Care Establishment (TPA) \\
\hline 48 & Establishment permit Community Library (TBM) \\
\hline 49 & Formal institutions Establishment Permit \\
\hline 50 & Permit the establishment of Secondary School Institutions \\
\hline 51 & Hospital Operating Permit Type C and D (IORS) \\
\hline 52 & Licensed Clinical Inpatient (IKRI) \\
\hline 53 & Provider License Outpatient Clinic (IPKRJ) \\
\hline 54 & Implementation of Clinical Laboratory Permit (IPLK) \\
\hline 55 & Permit Drug Stores (SITOB) \\
\hline 56 & Hospital Permit Type C \& D \\
\hline 57 & Construction Services Business License (IUJK) \\
\hline 58 & $\begin{array}{l}\text { Permission Form Local Resources Land \& Buildings, Border River Up or Channel } \\
\text { Managed Irrigation Department }\end{array}$ \\
\hline 59 & Permit Intake \& Utilization of Ground Water \\
\hline 60 & Home Placement Permit Office (Siper) \\
\hline 61 & Business License Timber Forest Product Primary Industry (IUIPHK) \\
\hline 62 & Services permission Tomb \\
\hline
\end{tabular}

Source: BP2T Malang. 


\section{Shifting Citizen Centric Model-Based Services}

The success of the licensing service reform policy, of strengthening the existing human resources, complementing the supporting instruments with adequate IT services, service strategies implemented by institutional finding the ideal shape. Institutional evolution that occurs in providing excellent service to the community hall starting from the formation of UPT with one-stop service system continues to turn into the service, to be strengthened institutional becomes an agency that is part of the Organizational Structure and Work Procedure (SOTK).

Change for change continues to improve service performance. Therefore, after BP2T work well with providing the best service to the community to make the performance of government favored by the public as measured by the index of satisfaction with the services provided.

The existence of an integrated service agency in Malang is empirically has managed to boost the efficiency and productivity of public services. However, it should be underlined also that the function of the integrated services actually nothing more than a front liner in the implementation of specific services. That is, this institution functioning himself as a "counter" the petition recipients that will continue the process to other functional units. In this condition, then it may be perceived as "Extra chain of bureaucracy" in service to the community. To avoid this negative impression, it is essential to services based on citizen centric in order to work in a professional manner, in the sense that, despite the addition of the bureaucracy, but the process of settlement services can be performed more quickly with better quality anyway. Here is a concept based on a service model citizen centric on BP2T Malang.

During institutional change for managing the system a good service to the public since 2004, but there is still a long path to the services provided. This is evident in the public's perception on the services provided. Therefore, the old model licensing service (old model) that progress should undergo a paradigm shift in providing service. It is also driven by the development of information technology era of globalization which will make Malang has high competitiveness in the national arena. Therefore, the new service model (New Model Service) will replace the licensing service paradigm in Malang.

The main emphasis in the New Model Service is an electronic-based services. Will involve the full participation of service users in accordance with the desired requirements. There are two (2) team in providing the services the administrative team that replaces the function of the Front liners, then the technical team that will replace the functions of the Back Office. Each has a different role namely:

1. Administration team play a role in collecting electronic information submitted by the user through the system which has been prepared by BP2T, then contribute also to distribute it to the appropriate authorities as technical team according designation/type of services provided by BP2T. This team has the right to reject the proposal when the document requirements are not met. 
2. Technical Team role to validate the feasibility of the proposals that have been distributed by the administrative team, and provide recommendations for the feasibility of proposals and then returned to the administrative team to deliver to the user.

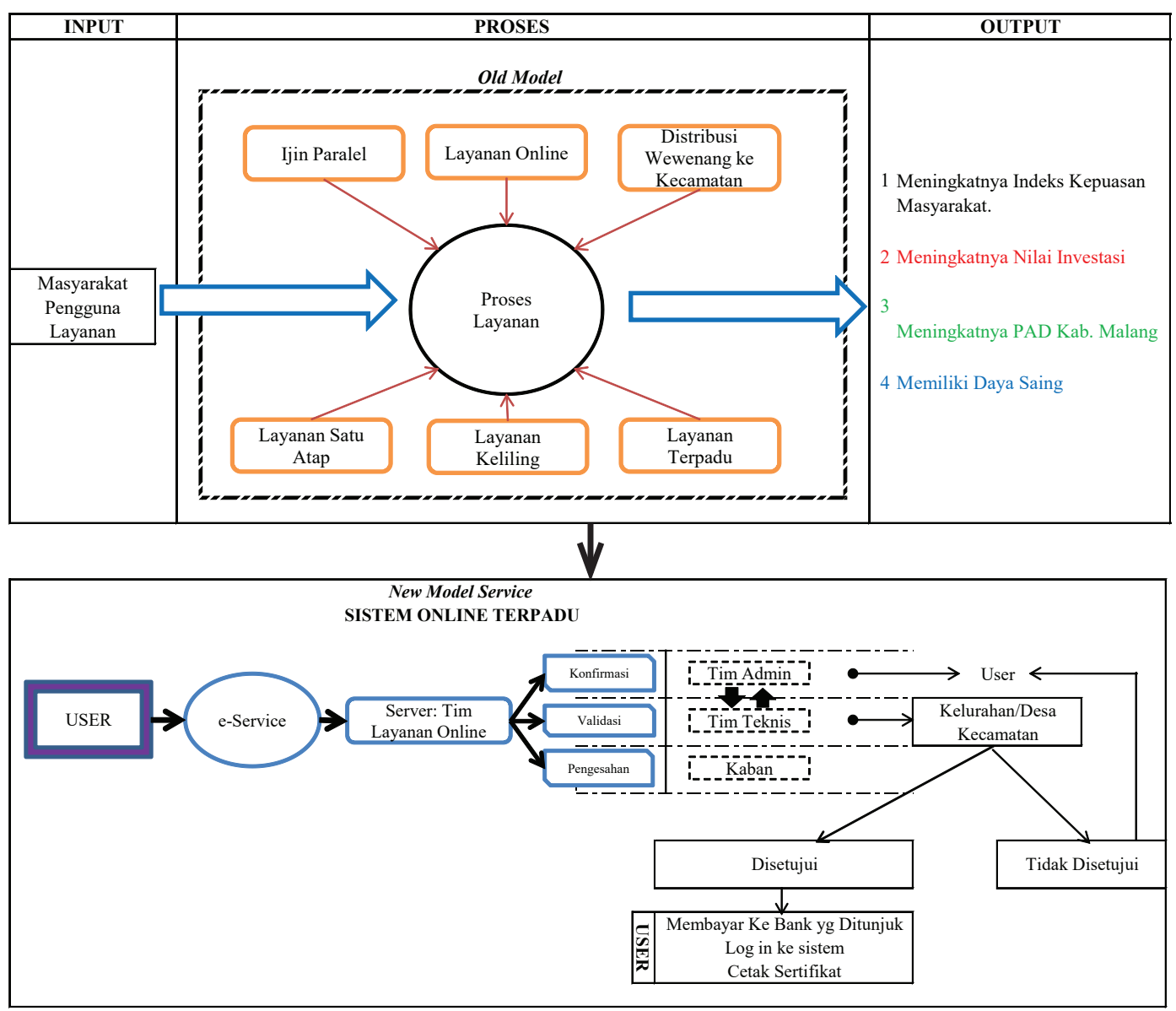

Based Licensing Model Citizen Centric Services

The whole process of the services performed by the user to the certificate issuance process is done "online" or through the online system then approval from the Head/Authorized Officer.

The management of licensing services through citizen-based system centric as has been described, indicates that the service functions that had been done by manually BP2T Malang regency, causing new problems in the history of licensing services in Malang. Then the service with the old format was replaced with a new paradigm by integrating all components of the service (product) into an online system (online). Such a service system provides several advantages, among others: People do not need to contact agencies that far apart, geographically Malang lebinya again take a very long mileage if to BP2T domiciled in Kepanjen. Besides the cost savings, avoid illegal payments (bribes), transparency of procedures and costs, In the context of the theory of "reinventing government", it can be said that such a system applied the 
concept of community owned, mission-driven, result oriented, customer oriented, and anticipatory government (Osborne and Gaebler, 2000; 65).

With a system of thisservice (new model of service), thentheprocedure of licensingservicesisassumedto be easier, faster, more accurate and more efficient.

\section{Challenges Faced in the Development Concept of Integrated Services}

Diera democratization, governance system adopted in the political system delivering leadership selection process directly at the central and regional levels. The selection process for the leadership exercised region demanding freedom of each individual citizen to participate in it through political vehicle is different. Therefore, the circulation of leadership that occurs will influence the policies of the previous, and even totally alter previous policy due to the personal popularity of a leader. This is a major challenge to the sustainability of the integrated service policies are currently underway. And do not rule out going to happen anyway polarization and politicization of bureaucracy when a change in leadership.

We need to know that we have yet to fully face bureaucracy totally changed. Change in the sense that regardless of the political interests of the ruling elites. For that, it needs a special mechanism to sustain this integrated service policy.

\section{Lesson Learned Policies and Critical Notes}

It is recognized that a policy process will never be in the empty space, which means that the policy has its own values contained therein and not be separated from the political system. Authority (2001) mentioned that the process of policy formulation can never be separated from political influence. This is because the policy positions that are in between the two political and public interest. The political process in a policy determine the quality of the policy. Therefore, the policy of the Government of Malang Regency in improving integrated service system is a very long political process. Lots of intrigue and interest therein to be consolidated. Therefore, need patience and 'patience' as well as the foresight of the leaders in addressing it.

The long process through which the Malang regency administration in finding the ideal shape of a care institution to make this district as a reference to other regions in the study of service systems are applied. All this can happen because the spirit of change that are embedded entrenched bureaucrats. The most important thing in the process of this change is the spirit of the evaluation. The evaluation does not alter the substance of the policy, but rather to reorganize the system - a system that is not the way policy. Theoretically this process mentioned by the Authority (2001), which refers to the concept Dunn that the policy will have a policy life cycle starting from policy issues, policy evaluation, determine develop alternative policies, elected laternatif elections, and policy implementation. 
Learning of the policy process through which the Government of Malang Regency in determining the ideal shape of a good service and make the policy right on target, then the system needs to be made in a policy setting. System setup is meant to function to regulate the circulation of any policy changes that can not be separated from the control substance so that the policy remains in the corridor policy objectives. This is done to control the practical political interests of certain elites. System settings can be shaped outline of the district service policies applicable in the long term.

\section{Conclusion}

The best step taken by the Government of Malang regency in improving this integrated service system should be a model for other regions across the country within the framework of the Unitary Republic of Indonesia. Although it has a different culture to provide services but is a nationally shared vision of providing excellent service to the people of Indonesia, especially the people in the area. To that end, in the process of policy measures undertaken by the Government of Malang Regency have learned a few points that can be used as a reference for other regions in Indonesia, namely:

1. Doctrinal changes made to foster a spirit for change from within ourselves, and for the institution;

2. Cut red tape by giving authority to the government district and village governments for services to the community affairs;

3. Utilize IT as an instrument of change and facilitate the public in accessing information services;

4. Reforming the institutions and institutional innovation of existing bureaucratic structures enhance function. The function of the bureaucratic structure enriched with expert knowledge in the field of IT, marketing, and recruiting capable staff base especially in the field of services;

5. Build a system that is transparent and accountable bureaucracy oriented to the welfare of the people; and

6. Building a new work culture and professionalism of human resources.

These six key points above should menajadi attention to areas in Indonesia to implement the same policy in accordance with the local culture. To that end areas need to learn to apply it by using the power of IT.

(C) Dwi Suharnoko, Umi Chayatin, Chandra Dinata, 2018 This work is licensed under a Creative Commons Attribution 4.0 International License 


\title{
REFERENCES
}

[1] Denhardt, Janet V., and Denhardt, Robert B., 2007, The New Public Service: Serving, Not Steering, ME Sharpe, Inc., Armonk, New York.

[2] Jasin, Mochammad, et al (Development Team), 2007, Implementation of Integrated Services at Regency / City: A Case Study of Yogyakarta, Malang, and Parepare, the Corruption Eradication Commission in Jakarta.

[3] Kearney, AT, 2009, How to Become a Citizen Centric Government, Atkearney Inc., Chicago, USA. Accessed from https://www.atkearney.com/documents/10192/6bc77242149A-4515-b4c7-3295ca1ab594 on 02/05/2013.

[4] Osborne, David and Ted Gaebler, 1992, Reinventing Government: How the Entrepreneurial Spirit is Transforming the Public Sector, Addison-Wesley.

[5] Ratminto, and Winarsih, AtikSepti, 2010, the Public Service Management: A Conceptual Model Development, Implementation of Citizen's Charter and Minimum Service Standards, Student Library, Yogyakarta.

[6] Sugiyono, 2009, Understanding Qualitative Research, Prints Fifth, Alfabeta, Bandung.

[7] Toruan, Denis L., (Editor), 2010, the Licensing Service Reform and Regional Development: Success Story Three Cities (Purbalingga, Makasar, and Banjarbaru), Indonesian Transparency Society (MTI), Jakarta.

[8] Authority, Samodra, 2001, the Political formulation of Public Policy, Graha Science, Yogyakarta.

\section{About the authors:}

Dwi Suharnoko - Public Administration Departement, Faculty of Social and Political Sciences, University of Merdeka Malang, dwi.suharnoko@unmer.ac.id

Umi Chayatin - Public Administration Departement, Faculty of Social and Political Sciences University of Merdeka Malang, ummichayatin@yahoo.com

Chandra Dinata - Public Administration Departement, Faculty of Social and Political Sciences University of Merdeka Malang, chand.dinata@unmer.ac.id

\section{Государственные услуги на основе принципа клиентоориентированности в Службе лицензирования провинции Маланг в эпоху децентрализации}

\author{
Д. Сухарноко, У. Чайтин, Ч. Дината \\ University of Merdeka, Malang
}

